\title{
Future Projection on Patriotism among School Students Using Delphi Technique
}

\author{
Saedah Siraj, Abd. Razak Zakaria, Norlidah Alias, Dorothy Dewitt, Ponnei Kannan, \\ Jeyanthy Ganapathy \\ Faculty of Education, University of Malaya, Kuala Lumpur, Malaysia \\ Email: saedah@um.edu.my, abdrazak@um.edu.my,drnorlidah@um.edu.my
}

Received June 25 ${ }^{\text {th }}$, 2012; revised July 24 $4^{\text {th }}, 2012$; accepted August $12^{\text {th }}, 2012$

\begin{abstract}
To date, past studies on projection of future education in Malaysia show that patriotism of the local secondary school students (in short, students) is yet to be conducted but currently studies are conducted on technology applications on both local curriculum content and teaching and learning, future curriculum of the local secondary school, future agro-science subject, and future moral of the Malaysian students. Benefiting from Delphi technique of Abraham Kaplan, this study attempts to see what the experts' projections are on students' spirit of patriotism in Malaysia, the impacts of spirit of patriotism on students' culture developments and curriculum implementation in the nation.
\end{abstract}

Keywords: Curriculum; Experts; Patriotism; Future Projection; Reflective

\section{Introduction}

To date, past studies on projection of future education in Malaysia show that patriotism of the local secondary school students (in short, students) is yet to be conducted but current studies are conducted on technology applications on both local curriculum content and teaching and learning (Siraj \& Abdullah, 2005; Siraj \& Saleh, 2003), future local workforce (Siraj \& Sulaiman, 2006), future curriculum of the local secondary school (Siraj \& Ali, 2008), future agro-science subject, and future moral of the Malaysian students (Siraj, 2001, 2002, 2004, 2008).

Benefiting from Delphi technique of Abraham Kaplan (Henson, 1980; Linstone \& Turoff, 1993; Rotondi \& Gustafson, 1996), this study attempts to see what the experts' projections are on students' spirit of patriotism in Malaysia, the impacts of spirit of patriotism on students' culture developments and curriculum implementation in the nation. Current researchers have exercised the Delphi technique not only in curriculum design, but in other fields as well (Slaughter, 1997). Patriotism is locally considered as one of the effective tools to boost virtuous-discipline future generation with experiential-reflective manner besides to defend them from the ill corrupted thoughts and ideologies. In addition, it is one of the multi-dimension subject-matters in Future Curriculum (Siraj, 2005, 2006, 2007a, 2007b, 2009; Siraj \& Malik, 2008). Moreover, the spirit of patriotism is one of the necessities to enrich the advance-dynamic-conscientious student.

The spirit of patriotism partly concerns with the insight or the inner self where physical, material, acts and even the behavior, is apparently shaped with patriotic character (Siraj, 2007a, 2007b). In other words, patriotism does not only entirely imply to what is perceived but also with inner self or experiential-reflective insight. This study aims to examine experts' projections on the spirit of patriotism among secondary school students in Malaysia. In addition, this study attempts to see the impacts of spirit of patriotism on secondary school students' culture development in the nation (Siraj, 2009; Siraj \& Aeria, 2005; Siraj \& Malik, 2008).

The processes of this study are based on two Japanese women's Nonaka's and Takeuchi's (1995) Knowledge Creation Model (KCM). KCM concerns with four central mechanisms, socialization, externalization, combination and internalization. Through these four mechanisms via adaptation of some Delphi technique procedures, the KCM processes occur. Beginning with Delphi technique's implementation process in which it initiates with group discussion activities to search early infofor this study, the central issue is spirit of patriotism. Then, researchers proceed by collecting info (talking with question and answer via phone or direct discussion) from interviews with respondents/experts. Normally, knowledge-character is with dynamic character and continues develops (Turban, \& Aronson, 2001). Accordingly, by merging all of the four mechanisms of KCM into Delphi technique procedures be the forerunner to structure the premise of spirit of patriotism, culture development, and curriculum implementation.

This study aims to get responses from the local patriotismexperts on spirit of patriotism among secondary school students in Malaysia as well as their projections on the impacts of spirit of patriotism on students' culture developments and also on curriculum implementation in the nation. These experts' responses (on spirit of patriotism) can be utilized by policy makers, curriculum designers, teachers' training institutions and schools, as an instrument to shape a future generation with experiential-reflective personality. This study (on future patriotism where it has connections with Future Curriculum as well as it is also one of a local essential factors in enhancing the advance, dynamic and conscientious students) is among one of the attempts to achieve Malaysia's Vision 2020 and the present One Malaysia policy.

\section{Research Questions}

This study attempts to answer three main research questions: 
1) What are the experts' projections on spirit of patriotism among secondary school students in Malaysia?

2) What are the experts' projections on the impacts of spirit of patriotism on secondary school students' culture development in Malaysia?

3) What are the experts' projections on the impacts of spirit of patriotism on curriculum implementation in Malaysia?

\section{Methodology}

\section{Framework of the Study}

Based on earlier studies by Hiltz and Turoff (1993), Siraj (2003, 2008a), Siraj and Ali (2008), Siraj and Abdullah (2005), Siraj and Saleh (2003) and Siraj and Sulaiman (2006), this study implemented the Delphi Technique for consensus attainment on future projection on spirit of patriotism among secondary school students in Malaysia, the impacts of spirit of patriotism on secondary school students' culture development in Malaysia, and the impacts of spirit of patriotism on curriculum implementation.

There are three central entities in Delphi's processes: the first, each expert is specialized in a different field and live at dissimilar locations (Adler \& Ziglio, 1996; Henson, 1980; Ziglio, 1996); the second, each expert merely presents her/his personal opinion; and the third, each expert is granted the chance to evaluate other experts' views on a similar topic (Siraj, 2008a; Glenn, 2000; Glenn \& Gordon, 2000, 2001, 2002, 2003, 2004, 2005, 2006, 2007, 2008). Beginning in the 1950s, at the Rand Corporation, Santa Monica, California, the Delphi Technique was exercised to project the future US security requirements (Siraj, 2008a, 2008d) while today, it is applied in various fields, for instance, in 1971, in Education, it was applied to gather the views of a panel of experts without placing them in a place (Cyphert \& Grant, 1971). Linstone \& Turoff (1975), Dalkey, Helmer \& Cochran (1969) and Gordon (1994) clarified that when the Delphi Technique is applied in a situational-study (other than the time and cost factor leading some experts to be unviable to sit together), it is advisable and even better for the researcher to acquire the experts' subjective views (Dalkey, 1969; Bijl, 1996; Dalkey \& Helmer, 1951, 1963). Both of them also emphasize that their above clarification has nothing to do with the accuracy in Analytical Approach application (Gordon, \& Hayward, 1968; Gordon \& Helmer, 1964; Helmer, 1972, 1977, 1981). Normally, there would be four Delphi Rounds (although in some cases it may be fewer or more). This process would be discontinued after a reasonable consensus attainment is achieved, and as the required information is obtained (Delbecq, Van de Ven, \& Gustafson, 1975; Jenkins \& Smith, 1994). Based on above discussions and earlier discussed study goals, the Delphi Technique is identified by the researchers as the most suitable approach to attain the experts' consensus on the future projection on spirit of patriotism among secondary school students in Malaysia.

\section{Panel of Experts}

The panel of experts for this study is not selected randomly; instead, they are selected according to three criteria. First, he or she is an expert who has acquired knowledge, experience, and has a major in a history-subject at any teachers' training institution. Second, he or she is an expert who has retained the post as history-teacher with more than ten years of history-subject teaching experience. The last criterion is he or she is an expert who is willing to take part in three Delphi Rounds.

\section{Data Collection Procedure}

Data collections are carried out on three Delphi Rounds and the details of each round are as follows:

\section{Data Collection Procedure for Delphi Round 1}

With the purpose to acquire information on the experts' projections on spirit of patriotism among secondary school students in Malaysia and the impacts of spirit of patriotism on their culture development and curriculum implementation in Malaysia, the respondents are interviewed in Delphi Round 1. The data accessed from these interviews are then formulated as the basis to construct the following Delphi Rounds' survey questions. Each expert is required to answer the submitted questionnaire via email. After receiving the answers, the data is analyzed using median and Inter Quartiles (IQ). Median is used to investigate the majority of experts (experts' consensus) while IQ is conducted to identify the relationships between each of the item or expert. The items are arranged according to year of appearance/consensus level based on each item's median score. Data analysis of Delphi Round 2 is attached in Appendixes 1, 2 and 3.

\section{Data Collection Procedure for Delphi Round 2}

Likert's 4-point scale is utilized to decide on a projected date of the patriotism effect on secondary school students in Malaysia. This scale is also utilized to attain experts' consensus on the impacts of patriotism on their (Malaysian secondary school students) culture development, and also the impacts of patriotism on curriculum implementation in the nation. The level of agreement is arranged based on Likert's 4-point scale: 1) $4=$ Strongly Agree; 2) 3 = Agree; 3) 2 = Disagree; 4) 1 = Strongly Disagree. For data analysis, the following values represent the occurrence of years: 1) 4 = 2009-2013; 2) 3 = 2014-2018; 3) 2 = 2019-2023; 4) 1 = after 20 years.

\section{Data Collection Procedure for Delphi Round 3}

The purpose of round 3 is to narrow the gap of views differences among the experts and indirectly heading to attain the consensus. Questionnaires of Delphi Round 3 are similar to those of Round 2. Both median and IQR are used to show the distribution of expert's views on each item. In this fashion, each expert is granted the chance to evaluate other experts' views in Delphi Round 2, thus, the expert may re-evaluate her/his answers in the next Round. The expert's answer of this round should be one of these: 1) constant with previous answer if that answer is inside IQR; 2) the expert may change her/his previous answer if that answer is outside of IQR; and 3) by offering reasons why her/his answer remains the same, and the expert is constant with her/his answer when that answer is outside of IQR. Statistic descriptive is utilized to analyze the data based on min, median, and IQR. All feedbacks from respondents (the experts) of the three Delphi Rounds would be analyzed as to achieve consensus of experts' future projections on spirit of patriotism among secondary school students in Malaysia and the impacts of spirit of patriotism on their culture development and curriculum implementation in Malaysia. All data analysis 
would be conducted using thematic approach as discussed in the following subtopic.

\section{Data Analysis Procedure}

Data accessed from the interviews of Round 1 is thematically-analyzed-performing analysis according to specific themes. In this study, three themes have been identified: firstly, spirit of patriotism (among secondary school students in Malaysia); secondly, the impacts of spirit of patriotism on culture development (of secondary school students); and thirdly, the impacts of spirit of patriotism on curriculum implementation. After receiving feedbacks from questionnaires of Delphi Rounds 2 and 3 then the data is analyzed based on min, median, and IQR. Projection on the occurrence years (the experts' levels of agreements) is based on the following median scores: 1) 4.5 $5=2009-2013$; 2) $3.5-4=2014-2018$; 3) $2.5-3.49=$ 2019-2023; and 4) 1.5 - 2.49 = after 20 years. The item's median is 3.5 to 4 when spirits of patriotism have an effect on secondary school students in Malaysia are between years of 2009 to 2013 (within the next 6 to 10 years). The spirits of patriotism has an effect on students are between years of 2014 to 2018 (within the next 11 to 15 years) when the item's median is 2.5 to 3.49 . When the item's median is 1.5 to 2.49 means the years of spirits of patriotism have an effect on students are between years of 2019 to 2023 (within the next 16 to 20 years); and when the item's median is 1 to 1.49 means the years of spirits of patriotism have an effect on students are after 20 years. Similar scores are used to select the years of the impacts of spirit of patriotism on students' culture development; and also the impacts of students' spirit of patriotism on curriculum implementation in Malaysia.

\section{Data Analysis}

Data analysis is conducted using Qualitative Approach for Delphi Round 1 and Quantitative Approach for Delphi Rounds 2 and 3. This data analysis shows the experts' projection years for the effect of patriotism on secondary school students in Malaysia. This data analysis is utilized to answer the following research questions: The first: What are the experts' projections on patriotism among secondary school students in Malaysia? The second: What are the experts' projections on the impacts patriotism on secondary school students' culture development in Malaysia? And the third: What are the experts' projections on the impacts of patriotism on curriculum implementation in Malaysia?

\section{Item Consensus}

The calculation of IQR is used to fix the relationships between each item and each expert that leads to the interpretation on the consensus of each item. The stages of consensus are fixed based on IQR as follows: 1 ) High consensus = IQR is 0 to $1 ; 2$ ) Moderate consensus = IQR is 1.01 to 1.99 ; and 3) Without consensus $=\mathrm{IQR}$ is 2.0 and above.

\section{Item Arrangement}

The data is analyzed to arrange certain items according to the arrangement based on the consensus' attainment and the years of projection. The item's arrangement is based on the item's earned median score of Likert's 4-point scale rates. The item is considered high when its median score is 4 while it is considered the lowest when its median score is 1 . Thus, it should be noted that in the analyzed data, the items are not arranged according to normal numerical arrangement; instead, it is based on the earned median score.

\section{Statistical Analysis}

The Central Tendency measurement is used in the statistical analysis of this study. Feedbacks from questionnaires of Delphi Rounds 2 and 3 are analyzed using Frequency of Central Tendency to calculate its median and IQR. According to Martino (1973) the median is the most accurate statistical approach to show the group views and it is also capable of showing each particular view of the expert. In fact, it is recognized that IQR is the most accurate calculation compared to min in showing the relationships between each expert and each item. The following discussed data shows responses of ten national secondary school history-expert teachers. The data is analyzed using the Central Tendency measurement: median and IQR.

\section{Analysis of Delphi Round 1}

The panel of experts is interviewed in Delphi Round 1 to gain their views on patriotism among secondary school students in Malaysia. The researchers analyzed the interviews data based on the following themes: First, the experts' projections on spirit of patriotism among secondary school students in Malaysia; Second, the impacts of patriotism on secondary school students' culture development in Malaysia; and third, the impacts of patriotism on curriculum implementation in Malaysia. Feedbacks from interviews of Delphi Round 1, which are analyzed for Delphi Round 2, shows the panel of expert have identified the following: First, 10 items that would spark patriotism among secondary school students in Malaysia; Second, 10 items on the impacts of patriotism on secondary school students' culture development in Malaysia; and 10 items on the impacts of spirit of patriotism on curriculum implementation in Malaysia. The findings of this Round are made as basis to design the following questionnaires.

\section{Analysis of Delphi Round 2}

The analysis of Delphi Round 2, the experts' answers of Delphi Round 1 and questionnaires of Delphi Round 2 are circulated to the panel of experts. In this Round, the scores of median and IQR are shown to the experts with the purpose that each one of them could change answer or maintain her/his Round 1 answers. The main purpose of this round is to reach consensus of the panel of experts. Each expert is requested to answer the questionnaires on the projection years which are arranged according to Likert's 4-points scale: The item's median is 3.5 to 4 when patriotism has an effect on secondary school students in Malaysia are between years of 2009 to 2013 (within the next 5 to 10 years). The patriotism has an effect on students are between years of 2014 to 2018 (within the next 11 to 15 years) when the item's median is 2.5 to 3.49 . When the item's median is 1.5 to 2.49 means the years of patriotism have an effect on students are between years of 2019 to 2023 (within the next 16 to 20 years); and when the item's median is 1 to 1.49 means the years of patriotism have an effect on students are after 20 years.

The Round is ended with the collection of experts' answers. 
The feedbacks of this Round are analyzed using the Frequency of Central Tendency, which is used to calculate its median and IQR. This analyzed data would be presented as to answer three Research Questions. Similarly, all items would be rearranged based on Projection Year or the experts' consensus based on median score. In order to confirm these findings, the questionnaires together with the summation of Delphi Round 2 data analysis will to be circulated again among the panel of experts at Delphi Round 3.

\section{Analysis of Delphi Round 3}

The similar questionnaires to Delphi Round 2 are circulated to the panel of experts. After the data is analyzed, the questionnaires of Delphi Round 3, the analysis of median and IQR analysis and the experts' previous answers are circulated again to each expert. In this Round, each expert is given the opportunity to reconsider their answers-either in maintaining their previous answers or changing them with different ones. The experts that decided in maintaining their answers were asked to explain their reasons for their decision. The main goal of this Round is to attain the highest consensus among the experts. In this Round, the data is analyzed based on median and IQR. The findings of this Round are utilized to answer the research questions. Delphi Round 3 shows the description of the following: First, patriotism among secondary school students in Malaysia; Second, the impacts of patriotism on secondary school students' culture development in Malaysia; and third, the impacts of patriotism on curriculum implementation in Malaysia.

Experts' projections on spirit of patriotism among secondary school students in Malaysia are illustrated at Table 1. For Inter Quartile (IQ), two items, 3 (reduction of ethnic polarization) and 4 (gap reduction at workplace, living place and education), obtained a score of 2 indicating that the experts did not reach a consensus for these items. As for the other items, a high consensus of experts is obtained. In terms of the median, a median of 4 is obtained for items 1 and 2 ("strengthen the spirit of unity" and "there is peace and harmony") while the rest of items received a median score of 3 indicating that the items. The former items indicated that the items would be held and practiced among the students between the years of 2009 to 2013 while the latter items would be held and practiced between the years of 2015 to 2020.

Experts' projections on the impact of spirit of patriotism on secondary school students' culture developments in Malaysia is illustrated at Table 2. Seven of the items in Table 2 received an IQ score of 1 indicating that these items achieved a high level of experts' consensus. As for the remaining three items ("appreciate contribution of other group and ethnic", "stronger neighborhood spirit" and "fly the Malaysian flag at each home"), the items did not receive consensus from the expert.

Table 3 shows the experts' projections on the impact of spirit of patriotism on curriculum implementation in Malaysia. Two items, item 1 (more strengthened patriotism aspects) and item 8 (stresses humanistic element that would be able to break personal and cultural crises) received an IQ score of 0 indicating that both items achieved a high level of experts' consensus. The remaining items obtained an IQ score of 1 showing that an average level of experts' consensus is achieved.

\section{Study Finding}

The followings are findings of the study:

\section{Study Finding 1}

Study findings of the experts' future-projections on patriotism among secondary school students in Malaysia show: First, the highest level of experts' consensus is obtained for 8 out of 10 items *(listed in next paragraph) on their projections on patriotism among secondary school students in Malaysia. Second, all of these eight items received a median score of 3 indicating that these items would be held and practiced by the students between the years of 2015 to 2020. Third, the item that received the highest level of experts' consensus is item 6 (a clear national development) with median score of 3 and an IQ score of 0 . Fourth, two items, item 1 (strengthen the spirit of unity) and item 2 (there is peace and harmony), obtained the least level of experts' consensus. Fifth, two items that did not obtain experts' consensus are item 3 (reduction of ethnic polarization)

Table 1.

Experts’ projections on spirit of patriotism among secondary school students in Malaysia.

\begin{tabular}{cccccc}
\hline No $^{*}$ & Items & Ranking & Median & Projection Year & Inter Quartile (IQ) \\
\hline 1 & Strengthen the spirit of unity & 1.5 & 4 & $2009-2013$ & 1 \\
2 & There is peace and harmony & 1.5 & 4 & $2009-2013$ & 2 \\
3 & Reduction of ethnic polarization & 6.5 & 3 & $2015-2020$ & 2 \\
4 & Gap reduction at workplace, living place and education & 6.5 & 3 & $2015-2020$ & 1 \\
5 & There is an inter-racial relation & 6.5 & 3 & $2015-2020$ & 1 \\
6 & A clear national development & 6.5 & 3 & $2015-2020$ & $2015-2020$ \\
7 & Celebrate National Day with full spirit & 6.5 & 3 & $2015-2020$ & 1 \\
9 & Responsibility on sustainable nation prosperities & 6.5 & 3 & 3 & $2015-2020$ \\
\hline
\end{tabular}

Note: ${ }^{*}=\mathrm{IQR}=\mathrm{Q} 3-\mathrm{Q} 1$. 
Table 2.

Experts' projections on the impact of spirit of patriotism on secondary school students' culture developments in Malaysia.

\begin{tabular}{|c|c|c|c|c|}
\hline $\mathrm{No}^{*}$ & Item & Ranking & Median & IQ \\
\hline 1 & Help each other & 6.5 & 3 & 1 \\
\hline 2 & Appreciate contribution of other group and ethnic & 6.5 & 3 & 2 \\
\hline 3 & Tolerant to the culture of other ethnic & 1.5 & 3.5 & 1 \\
\hline 4 & Respect the culture of other ethnic & 6.5 & 3 & 1 \\
\hline 5 & Celebrate together celebrations of other ethnics & 6.5 & 3 & 1 \\
\hline 6 & There is a Malaysian identity & 6.5 & 3 & 1 \\
\hline 7 & Dress that symbolizes the culture of Malaysia & 6.5 & 3 & 1 \\
\hline 8 & Stronger neighborhood spirit & 6.5 & 3 & 2 \\
\hline 9 & Celebrate National Day as a Malaysian citizen celebration & 1.5 & 3.5 & 1 \\
\hline 10 & Fly the Malaysian flag at each home & 6.5 & 3 & 2 \\
\hline
\end{tabular}

Note: ${ }^{*}=\mathrm{IQR}=\mathrm{Q} 3-\mathrm{Q} 1$.

Table 3.

Experts' projections on the impact of spirit of patriotism on curriculum implementation in Malaysia.

\begin{tabular}{|c|c|c|c|c|}
\hline $\mathrm{No}^{*}$ & Item & Ranking & Median & IQ \\
\hline 1 & More strengthened patriotism aspects & 7 & 3 & 0 \\
\hline 2 & Stresses on nationhood and citizenship & 7 & 3 & 1 \\
\hline 3 & Education Philosophy with dynamic and futuristic characters & 7 & 3 & 1 \\
\hline 4 & $\begin{array}{c}\text { School syllabus is able to shape Knowledge-society, skill gains, good personality and competent } \\
\text { of problem-solving }\end{array}$ & 1.5 & 3 & 1 \\
\hline 5 & Able to strengthen basic human development to assist student to own social and moral vision & 7 & 3 & 1 \\
\hline 6 & Aid in decision-making and rational and logic decision & 1.5 & 3 & 1 \\
\hline 7 & Theories of teaching should utilize discovery-approach, personal development and criticizing & 7 & 3 & 1 \\
\hline 8 & Stresses humanistic element that would be able to break personal and cultural crises & 7 & 3 & 0 \\
\hline 9 & Breeds the brave spirit of record-breaking for the nation & 7 & 3 & 1 \\
\hline 10 & Reform preparations that is relevant to changing condition and time without leaving good values & 3 & 3 & 1 \\
\hline
\end{tabular}

Note: ${ }^{*}=\mathrm{IQR}=\mathrm{Q} 3-\mathrm{Q} 1$.

and item 4 (gap reduction at workplace, living place and education). These five data analysis facts answered research question 1 : "What are the experts' projections on spirit of patriotism among secondary school students in Malaysia?" *List of the 8 Items: Items 1 (Strengthen the spirit of unity), 2 (There is peace and harmony), 5 (There is an inter-racial relation), 6 (A clear national development), 7 (Celebrate National Day with full spirit), 8 (Responsibility on sustainable nation prosperities), 9 (Appreciate historical figures' services and contributions), and 10 (Total excellent is producing calibers leaders).

\section{Study Finding 2}

Study findings of the experts' projections on the impact of patriotism on secondary school students' culture developments in Malaysia are as follows: First, 7 out of 10 items *(listed in next paragraph) obtained the highest level of experts' consensus on the impact of patriotism on secondary school students' culture developments in Malaysia. Second, two items, item 3 (tolerant to the culture of other ethnic) and item 9 (Celebrate National Day as a Malaysian citizen celebration) received the highest level of consensus of the experts. Third, the experts do not attain consensus on three items, item 2 (appreciate contribution of other group and ethnic), item 8 (stronger neighborhood spirit), and item 10 (fly the Malaysian flag at each home). All these three data analysis answers the research question 2: "What are the experts' projections on the impacts of spirit of patriotism on secondary school students' culture development in Malaysia?” *List of the 7 Items: Items 1 (Help each other), 3 (Tolerant to the culture of other ethnic), 4 (Respect the culture of other ethnic), 5 (Celebrate together celebrations of other ethnics), 6 (There is a Malaysian identity), 7 (Dress that symbolizes the culture of Malaysia), and 9 (Celebrate National Day as a Malaysian citizen celebration). 


\section{Study Finding 3}

Study findings of the experts' projections on the impact of patriotism on curriculum implementation in Malaysia shows that the experts attain the highest level consensus on all items *(listed in next paragraph) related to the impact of spirit of patriotism on curriculum implementation in Malaysia; and two items (item 1 and 8) attained the highest level of experts' consensus with the median score of 3 and an IQR score of 0 thus answering research question 3: "What are the experts' projections on the impacts of spirit of patriotism on curriculum implementation in Malaysia?" *List of the 10 Items: Items 1) (More strengthened patriotism aspects); 2) (Stresses on nationhood and citizenship); 3) (Education Philosophy with dynamic and futuristic characters); 4) (School syllabus is able to shape Knowledge-society, skill gains, good personality and competent of problem-solving); 5) (Able to strengthen basic human development to assist student to own social and moral vision); 6) (Aid in decision-making and rational and logic decision); 7) (Theories of teaching should utilize discovery-approach, personal development and criticizing); 8) (Stresses humanistic element that would be able to break personal and cultural crises); 9) (Breeds the brave spirit of record-breaking for the nation); and 10) (Reform preparations that is relevant to changing condition and time without abandoning good values).

\section{Conclusion}

First, the experts attained consensus on 8 out of 10 items ("Strengthen the spirit of unity," "There is peace and harmony," "There is an inter-racial relation," "A clear national development," "Celebrate National Day with full spirit," "Responsibility on sustainable nation prosperities," "Appreciate historical figures' services and contributions" and "Total excellent is producing calibers leaders") on their projections on spirit of patriotism among secondary school students in Malaysia. In addition, they also agreed that the eight items would be held and practiced by the students between the years of 2015 to 2020 . Nevertheless, they did not reach consensus on two items ("Reduction of ethnic polarization" and "Gap reduction at workplace and living place and education”) thus answering research question 1: "What are the experts' projections on spirit of patriotism among secondary school students in Malaysia?”

Secondly, the experts attained consensus on 7 out of 10 items ("Help each other," "Tolerant to the culture of other ethnic," "Respect the culture of other ethnic," "Celebrate together celebrations of other ethnics," "There is a Malaysian identity," "Dress that symbolizes the culture of Malaysia," and "Celebrate National Day as a Malaysian citizen celebration") on the impact of patriotism on secondary school students' culture developments in Malaysia. However, they did not reach consensus on three items ("Appreciate contribution of other group and ethnic," "Stronger neighborhood spirit" and "Fly the Malaysian flag at each home") thus answering research question 2: "What are the experts' projections on the impacts of spirit of patriotism on secondary school students' culture development in Malaysia?”

Thirdly, the experts attained consensus on all ten items ("More strengthened patriotism aspects," "Stresses on nationhood and citizenship," "Education Philosophy with dynamic and futuristic characters," "School syllabus is able to shape Knowledge-society, skill gains, good personality and competent of problem-solving," "Able to strengthen basic human development to assist student to own social and moral vision," "Aid in decision-making and rational and logic decision," "Theories of teaching should utilize discovery-approach, personal development and criticizing," "Stresses humanistic element that would be able to break personal and cultural crises," "Breeds the brave spirit of record-breaking for the nation" and "Reform preparations that is relevant to changing condition and time without abandoning good values") on the impact of patriotism on curriculum implementation in Malaysia thus answering research question 3: "What are the experts' projections on the impacts of spirit of patriotism on curriculum implementation in Malaysia?”

\section{REFERENCES}

Adler, M., \& Ziglio, E. (Eds.). (1996). Gazing into the oracle. Bristol, PA: Kingsley.

Amara, R. C., \& Salancik, G. R. (1971-1972). Forecasting: From conjectural art toward science. Technological Forecasting and Social Change, 3, 415-426. doi:10.1016/S0040-1625(71)80029-X

Bijl, R. (1996). The use of the Delphi Method in constructing scenarios on the future of mental health and mental health care. In: M. Adler, \& E. Ziglio (Eds.), Gazing into the oracle: The Delphi method and its application to social policy and public health (pp. 133-155). London: Kingsley.

Cyphert, F., \& Grant, W. (1971). The Delphi technique: A case study. Phi Delta Kappan, 42, 272-273.

Dalkey, N. (1969). An experimental study of group opinion: The Delphi method. Futures, 1, 408-426. doi:10.1016/S0016-3287(69)80025-X

Dalkey, N., \& Helmer, O. (1951). The use of experts for the estimation of bombing requirements: A project Delphi experiment. Santa Monica, CA: Rand.

Dalkey, N., \& Helmer, O. (1963). An experimental application of the Delphi method to the use of experts. Management Science, 9, 458467. doi:10.1287/mnsc.9.3.458

Dalkey, N. C., Brown, B., \& Cochran, S. (1969). The Delphi Method III: Use of self ratings to improve group estimates. Santa Monica, CA: Rand.

Delbecq, A. L., Van de Ven, A. H., \& Gustafson, D. H. (1975). Group techniques for program planning: A guide to nominal group and Delphi processes. Glenview, IL: Foresman.

Glenn, J. C. (2000). Strategic directions for science and technology in the 21st century (pp. 1-23). Power Point Presentation for Keynote Speech at IECON-2000, Nagoya. URL (retrieved 30 May 2000). http://www.geocities.com/ acunu/millenium/resume/jglenn.html

Glenn, J. C., \& Gordon, T. J. (1996). The millennium project report. ULR (last checked 30 May 2009) http://nko.org/millennium/MillenniumProject.html

Glenn, J. C., \& Gordon, T. J. (2000). State of the future at the millennium. Washington DC: American Council for the United Nations University.

Glenn, J. C., \& Gordon, T. J. (2001). 2001 state of the future. Washington, DC: American Council for the United Nations University.

Glenn, J. C., \& Gordon, T. J. (2002). 2002 state of the future. Washington, DC: American Council for the United Nations University.

Glenn, J. C., \& Gordon, T. J. (2003). 2003 state of the future. Washington, DC: American Council for the United Nations University.

Glenn, J. C., \& Gordon, T. J. (2004). 2004 state of the future. Washington, DC: American Council for the United Nations University.

Glenn, J. C., \& Gordon, T. J. (2005). 2005 state of the future. Washington, DC: American Council for the United Nations University.

Glenn, J. C., \& Gordon, T. J. (2006). 2006 state of the future. Washington, DC: American Council for the United Nations University.

Glenn, J. C., \& Gordon, T. J. (2007). 2007 State of the future. Washington, DC: World Federation of UN Associations and American Council for the United Nations University.

Glenn, J. C., Gordon, T. J., \& Florescue, E. (2008). The Millennium 
Project: State of the future. Washington, DC: World Federation of UN Associations.

Gordon, T. J. (1965). The future. New York: St. Martin’s.

Gordon, T. J. (1994). Cross Impact Analysis: A publication of United Nations Development Program's African Futures Project in collaborations with the United Nations University's Millennium Project Feasibility Study: Phase II. URL (last checked 13 March 2009). http://www3.interscience.wiley.Com/cgi-bin/abstract/104524055/AB STRACT?CRETRY $=1 \&$ SRET RY $=0$

Gordon, T. J., \& Hayward, J. J. (1968). Initial experiments with the cross-impact Matrix Method of forecasting. Futures, 1, 100-116. doi:10.1016/S0016-3287(68)80003-5

Gordon, T. J., \& Helmer, O. (1964). Report on a long-rangeforecasting study. Santa Monica, CA: Rand.

Helmer, O. (1967a). Analysis of the future: The Delphi method. Santa Monica, CA: Rand.

Helmer, O. (1967b). Systematic use of expert opinions. Santa Monica, CA: Rand.

Helmer, O. (1972). Cross impact gaming. Futures, 4, 149-167. doi:10.1016/0016-3287(72)90039-0

Helmer, O. (1977). Problems in futures research: Delphi and causal cross-impact analysis. Futures, 9, 17-31. doi:10.1016/0016-3287(77)90049-0

Helmer, O. (1981). Reassessment of cross-impact analysis. Futures, 13, 389-400. doi:10.1016/0016-3287(81)90124-5

Henson, L. L. (1980). The use of the Delphi technique: University community involvement in the creation of a Library Building Program at Florida Institute of Technology. Digital Dissertations, UMI, ProQuest. (AAT 8104260).

Hiltz, S. R., \& Turoff, M. (1993). The network nation: Human communication via computer (Rev. ed.). Cambridge, MA: MIT Press.

Jenkins, D. A., \& Smith, T. E. (1994). Applying Delphi methodology in family therapy research. Contemporary Family Therapy, 16, 411-430. doi:10.1007/BF02197902

Kahn, H., \& Wiener, A. J. (1967). The year 2000: A framework for speculation on the next thirty-three years. London: MacMillan Publishing Company.

Kahn, H., Brown, C., \& Martel, L. (1976). The next 200 years: A scenario for America and the world. New York: Morrow.

Linstone, H. A., \& Turoff, M. (Eds.) (1993). The Delphi method: Techniques and applications (Rev. ed.). Reading, MA: Addison-Wesley.

Martino, J. P. (1973). An introduction to technological forecasting. New York: Routledge.

Nonaka, I., \& Takeuchi, H. (1995). The Knowledge-Creating company: how Japanese companies create the dynamics of innovation. New York: Oxford University Press.

Rotondi, A., \& Gustafson, D. (1996). Theoretical, methodological and practical issues arising out of the Delphi method. In: M. Adler, \& E. Ziglio (Eds.), Gazing into the oracle: The Delphi method and its application to social policy and public health. London: Kingsley.

Siraj, S. (1999). Curriculum for thinkers, inventors and professionals. Curriculum Journal, 1, 42-56.

http://www.ppk.kpm.my/html/edu\%20resource/eduerbit99siri2.htm

Siraj, S. (Ed.) (2001). Perkembangan kurikulum: Teori dan amalan (2nd ed.). Selangor: Alam Pintar Enterprise.

Siraj, S. (2002). The policy and aim of the future curriculum. In S. Hussin (Ed.), Inovasi dasar pendidikan: Amalan perspektif system dan inovasi (pp. 67-79). Kuala Lumpur: Penerbit Universiti Malaya.

Siraj, S. (2003). M-learning in curriculum implementation. Proceeding, Power Point Presentation, and Paper delivered at IAACS First World Conference on Curriculum Studies 2003, East China Normal University, Shanghai, China. Paper presented, Power Point Presentation, \& Proceeding of the First World Curriculum Studies Conference 2003, East China Normal University, Shanghai, China.

http://www.shaghai.tuxcafe.org/Shanghai-2003/groupe_de_3 http://www.babelfish.yahoo.com/translate_url?trurl=http\%3A\%2F\% 2Fwww.ses.ecnu.edu.cn\%2

Siraj, S. (2004). Mobile learning in future curriculum. Masalah Pendidikan, 27, 129-141.

http://www.myais.fsktm.um.edu.my/5305/1/12.pdf

Siraj, S. (2005). Future curriculum: Can it be measured? In S. H. Loke,
A. T. Putih, S. E. Lee, S, Sebestian, \& A. Asmawi (Eds.), Pedagogi merentas kurikulum (Pedagogy across curriculum). Mount Laurel: PTS Professional.

Siraj, S. (2006b). Measuring the future for better possibilities in Malaysia's and Indonesia's education planning. Keynote Address \& Power Point Presentation at Seminar on National Education, Bandung: University of Education Indonesia. http://www2.kompas.com/ver1/Dikbud/0612/22/122259.htm

Siraj, S. (2007a). Future-oriented curriculum for higher education: A new challenge of planning. In S. Hussin, M. Samuel, M. O. C. Sooi, F. Hashim, R. M. R. Hussain, \& A. J. Othman (Eds.), The whirwind in educational management and policy (pp. 99-118). Kuala Lumpur: University Malaya Press.

Siraj, S. (2007b). Future-oriented curriculum planning. Keynote Address \& Power Point Presentation at International Seminar on Education, Makassar: Makassar State University.

Siraj, S. (2008a). Kurikulum masa depan (Future curriculum). Kuala Lumpur: Penerbit Universiti Malaya.

Siraj, S. (2008b). The general core competencies in the Malaysian curriculum. International Collaborative Seminar on Core Competencies of Human Development in Education. Kuala Lumpur \& Seoul: Faculty of Education, University of Malaya \& Department of Education, Seoul National University.

Siraj, S. (2008c). Pendekatan kurikulum untuk pembinaan negara masa depan (Curriculum approach for the development of the future nation). Inaugural Speech, Kuala Lumpur: University of Malaya, Office of International Relation and Corporate, University of Malaya. http://mediunewscuts.blogspot.com/2008/04/kurikulum-pendidikan-s umber-mencorak.html

Siraj, S. (2008d). School improvement based on future-oriented curriculum planning. International Seminar on School Improvement, Kuala Lumpur: Institute of Principalship, University of Malaya.

Siraj, S. (2008e). Perancangan kurikulum berasaskan penyelidikan masa depan (Future research-based curriculum planning). International Seminar on Educational Research, Bandung: University of Education Indonesia.

Siraj, S. (2009). Future curriculum planning. Keynote Address, Power Point Presentation, \& Paper Delivered at International Seminar on Future Education, Jakarta: University of Hamka.

http://www.depkominfo.go.id/2009/01/23/sudah-saatnya-dunia-pendi dikan-menyusun-kurikulum-masa-depan/

Siraj, S., \& Aeria, L. A. (2005). Teacher burnout in the implementation of curricular changes: How serious? Kuala Lumpur: University of Malaya, Faculty of Education.

Siraj, S., \& Malik, A. A. (2008). Future-oriented curriculum planning. Journal of Education, 2, 27-59. http://www.ije.jurnal.upi.edu

Siraj, S., \& Ali, A. (2008). Principals' projections on the Malaysian secondary school future curriculum. International Education Studies, 1, 61-78.

Siraj S., \& Abdullah, F. (2005). Future projection on the technology applications in the curriculum content and evaluation at secondary level: a Delphi study. Jurnal Pendidikan, Journal of Educational Research, 25, 5-26. http://www.myais.fsktm.um.edu.my/5387

Siraj, S., \& Sulaiman, N. (2006). Future projection on the workforce need and the improvement of education system. Jurnal Pendidikan, Journal of Educational Research, 26, 189-210. http://www.myais.fsktm.um.edu.my-Jangkaan

Siraj, S., \& Saleh, M. P. (2003). Technology applications in teaching and learning at secondary school: future projection. Jurnal Pendidikan, Journal of Educational Research, 23, 123-139. http://www.myais.fsktm.um.edu.my-Aplikasi

Slaughter, R. (1997). Implementing foresight for future generations. In R. Slaughter (Ed.), The knowledge base of Futures Studies. Volume 3: Directions and outlooks. Hawthorn, VIC: Media. http://www.sciencedirect.com/science?_sdarticle.pdf

Ziglio, E. (1996). The Delphi Method and its contribution to decision making. In M. Adler, \& E. Ziglio (Eds.), Gazing into the oracle: The Delphi method and its application to social policy and public health (pp. 3-33). London: Kingsley. 